ARTICLE

Received 1 Apr 2014 | Accepted 6 Aug 2014 | Published 17 Sep $2014 \quad$ DOl: 10.1038/ncomms5923

\title{
Subduction of the oceanic Hikurangi Plateau and its impact on the Kermadec arc
}

Christian Timm¹, Bryan Davy¹, Karsten Haase ${ }^{2}$, Kaj A. Hoernle ${ }^{3}$, lan J. Graham¹, Cornel E.J. de Ronde ${ }^{1}$, Jon Woodhead ${ }^{4}$, Dan Bassett ${ }^{5}$, Folkmar Hauff ${ }^{3}$, Nick Mortimer ${ }^{6}$, Hannu C. Seebeck ${ }^{1}$, Richard J. Wysoczanski ${ }^{7}$, Fabio Caratori-Tontini ${ }^{1} \&$ John A. Gamble ${ }^{8}$

Large igneous province subduction is a rare process on Earth. A modern example is the subduction of the oceanic Hikurangi Plateau beneath the southern Kermadec arc, offshore New Zealand. This segment of the arc has the largest total lava volume erupted and the highest volcano density of the entire Kermadec arc. Here we show that Kermadec arc lavas south of $\sim 32^{\circ} \mathrm{S}$ have elevated $\mathrm{Pb}$ and $\mathrm{Sr}$ and low $\mathrm{Nd}$ isotope ratios, which argues, together with increasing seafloor depth, forearc retreat and crustal thinning, for initial Hikurangi Plateau-Kermadec arc collision $\sim 250 \mathrm{~km}$ north of its present position. The combined data set indicates that a much larger portion of the Hikurangi Plateau (the missing Ontong Java Nui piece) than previously believed has already been subducted. Oblique plate convergence caused southward migration of the thickened and buoyant oceanic plateau crust, creating a buoyant 'Hikurangi' mélange beneath the Moho that interacts with ascending arc melts.

\footnotetext{
${ }^{1}$ GNS Science, PO Box 30-368, Lower Hutt 5040, New Zealand. ${ }^{2}$ Geozentrum Nordbayern, Universität Erlangen-Nürnberg, Schlossgarten 5, 91054 Erlangen, Germany. ${ }^{3}$ GEOMAR Helmholtz Centre for Ocean Research, FB4, Wischhofstrasse 1-3, 24148 Kiel, Germany. ${ }^{4}$ School of Earth Sciences, University of Melbourne, Parkville, Victoria 3010, Australia. ${ }^{5}$ Department of Earth Sciences, University of Oxford, Oxford OX1 3AN, UK. ${ }^{6}$ GNS Science, Private Bag 1930, Dunedin 9054, New Zealand. ${ }^{7}$ National Institute of Water and Atmospheric Research, Private Bag 14901, Wellington 6241, New Zealand. ${ }^{8}$ School of Geography, Environment and Earth Sciences, Victoria University of Wellington, PO Box 600, Wellington 6140, New Zealand. Correspondence and requests for materials should be addressed to C.T. (email: c.timm@gns.cri.nz).
} 
$\mathrm{T}$ he formation of large igneous provinces (LIPs) represents one of the most extreme volcanic events on Earth, characterized through eruption of vast amounts of lava in a geologically short period ${ }^{1}$. Oceanic LIPs either accrete and obduct, adding to the continental landmass ${ }^{2-4}$ or in rare cases recycle back into the Earth's mantle via subduction. Known examples of oceanic plateau subduction include the Cretaceous Caribbean Plateau, accreting at and subducting/underthrusting beneath the Greater Antilles on the Caribbean Plate and the south-eastern part of the Ontong Java Plateau presently subducting beneath the Solomon Islands at the north SolomonKilinailau trench. Both examples involve complex tectonic processes, such as impact-related accretion of oceanic plateau crust and the change of subduction polarity ${ }^{5-8}$. However, subduction of one tectonic plate beneath another has driven geochemical cycling and the formation of the Earth's crust since $\sim 3,500 \mathrm{Myr}^{9}$. It has been known for decades that volcanic arcs are the result of that subduction process, as the descending plate dehydrates, causing partial melting in the overlying mantle. Consequently, arc lavas carry geochemical signals from the subducting plate, which includes the sediment cover, altered oceanic crust and serpentinized mantle ${ }^{10-12}$. In addition, signals of subducting intraplate seamounts (or LIPs) with geochemical compositions different to the subarc mantle can be traced in arc lavas ${ }^{13,14}$. Tracing the subduction cycle of such geological features provides an improved understanding of mantle-flow pattern and may explain the variability in eruptive behaviour and style of hydrothermal activity on the overriding plate ${ }^{15}$.

A globally unique example of single polarity oceanic plateau subduction is the Hikurangi Plateau presently subducting beneath the southern Kermadec arc and the North Island of New Zealand (Fig. 1) ${ }^{16-19}$. Subduction of 15-23-km thick, altered and buoyant Hikurangi Plateau crust, that is host to large seamounts ${ }^{19,20}$, must not only have a strong effect on tectonic erosion and the local plate stress regime, but also on volatile element budgets in the overlying mantle. This in turn suggests significant implications for the petrogenesis and eruptive behaviour of arc volcanoes, fluid-flow in their associated hydrothermal systems, and element transfer to the oceans. The Hikurangi Plateau is believed to have formed as part of Ontong Java Nui during the 'greater Ontong Java event' $\sim 120$ Myr ago, one of the world's most extreme volcanic events, covering $\sim 1 \%$ of the Earth's surface ${ }^{18,21,22}$. As noted by Chandler et al. ${ }^{22}$, a large part of the Hikurangi Plateau connecting its western and northern margin with the Ontong Java and Manihiki plateaus either does not exist or has already been subducted.

In this study we present new $\mathrm{Sr}-$, Nd-, and $\mathrm{Pb}$-isotope data from Kermadec arc and Hikurangi Plateau lavas (Fig. 1) which, when combined with published isotope and satellite gravity data and bathymetry, show large-scale geochemical and geophysical variations along the length of the Kermadec arc, enabling us to better understand the processes related to LIP subduction and thus identifying the 'missing' piece of Ontong Java Nui.

\section{Results}

Geological background. The $\sim 1,300-\mathrm{km}$ long, intra-oceanic, mostly submarine Kermadec arc system results from PacificAustralian Plate convergence and forms the southern part of the Tonga-Kermadec arc system that extends $\sim 2,500 \mathrm{~km}$ north of New Zealand. The Kermadec arc is one of the worlds most volcanically and hydrothermally active arc systems, with $\sim 75 \%$ of the 33 major volcanoes being hydrothermally active ${ }^{15}$. Subduction velocities decrease from the fastest convergence rates on Earth of $\sim 24 \mathrm{~cm}$ per year at the northern end of the Tonga arc system ${ }^{23}$, to $\sim 5 \mathrm{~cm}$ per year along the southern Kermadec arc. The sediment veneer on the incoming Pacific Plate, changes in thickness and

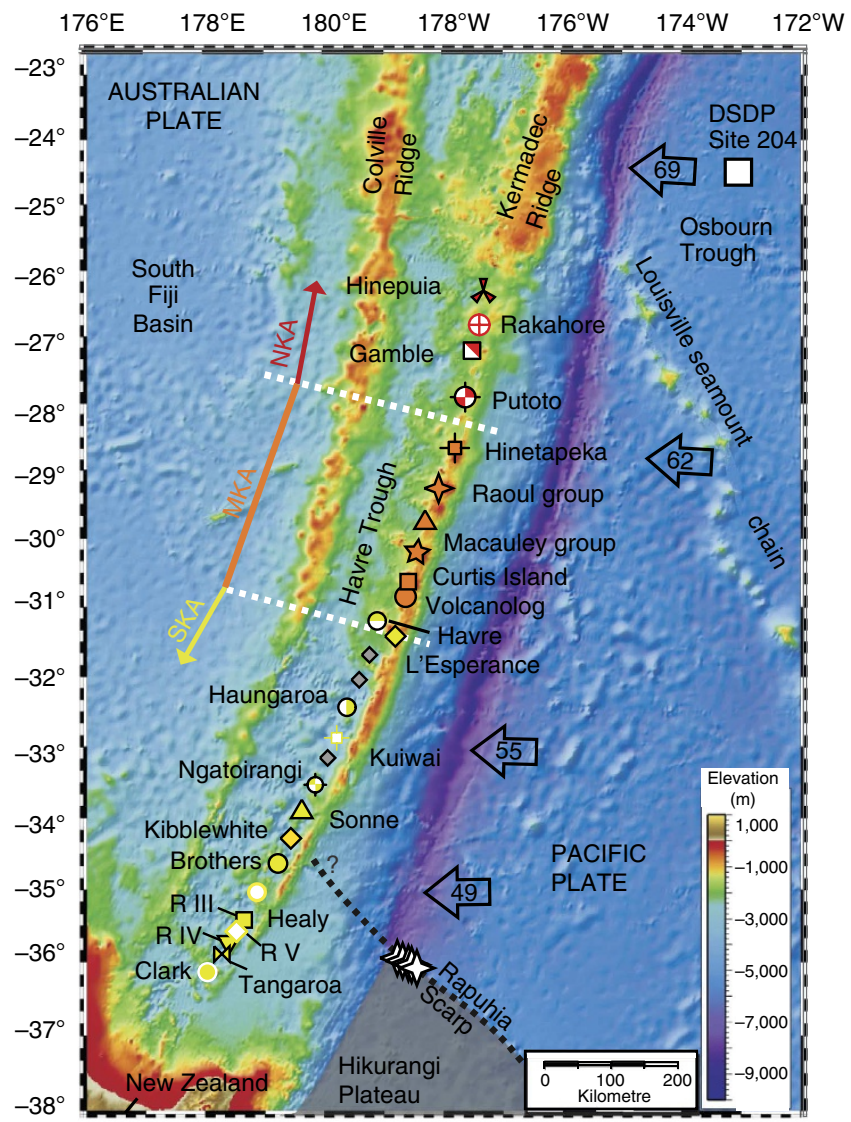

Figure 1 | Bathymetric map of the Kermadec arc-Havre Trough backarc system. Symbols mark the Kermadec arc volcanic centre locations discussed in this paper, with coloured symbols used for the different volcanic centres from which isotopic data are available; the grey symbols are for volcanoes for which no isotope data are available. White stars mark the location of additional Hikurangi Plateau samples used in this study. The numbers in the arrows are subduction velocities, as in ref. 23. For the purpose of this study we separate the Kermadec arc into three segments on the basis of the location of the volcanic front behind or on the Kermadec Ridge: (1) the northern Kermadec arc (NKA) between $\sim 25^{\circ}$ and $28.5^{\circ} \mathrm{S}$, (2) the mid Kermadec arc (MKA) between $\sim 29$ and $\sim 32^{\circ} \mathrm{S}$ and (3) the southern Kermadec arc (SKA) between $32^{\circ}$ and $37^{\circ}$ S. DSDP, Deep Sea Drilling Programme.

composition from $\sim 200 \mathrm{~m}$ of pelagic sediments near $\sim 25^{\circ} \mathrm{S}$ (that is, DSDP Site 204; for example, ref. 24; Fig. 1) to $\geq 500 \mathrm{~m}$ of predominantly terrigeneous sediments near $\sim 36^{\circ} \mathrm{S}$ (ref. 25).

North of $\sim 28.5^{\circ} \mathrm{S}$, the Kermadec arc front volcanoes are located in the Havre Trough backarc immediately west of the relatively old and inactive Kermadec Ridge before they merge with the Kermadec Ridge between $\sim 29^{\circ} \mathrm{S}$ and $\sim 32^{\circ} \mathrm{S}$. At $\sim 32^{\circ} \mathrm{S}$, the arc front shows a sudden $\sim 15 \mathrm{~km}$ offset into the Havre Trough accompanied by $\sim 500 \mathrm{~m}$ average seafloor deepening ${ }^{15,26}$. South of $32^{\circ} \mathrm{S}$, the majority of the volcanic front volcanoes are located behind the Kermadec Ridge and the forearc narrows by $\sim 75 \mathrm{~km}$ from a gently trenchward dipping and $\sim 200-\mathrm{km}$ wide to $\sim 125-\mathrm{km}$ wide ${ }^{27}$. These authors also inferred a westward trench retreat of $\leq 50 \mathrm{~km}$, and that the forearc inner trench margin south of $32^{\circ} \mathrm{S}$ subsided by $\leq 4 \mathrm{~km}$, summing up to a loss in volume of $\sim 400 \mathrm{~km}^{3}$ compared with the north.

South of $\sim 35^{\circ} \mathrm{S}$, subduction of the Cretaceous Hikurangi Plateau beneath the southern Kermadec arc is accompanied by an average shoaling of $\sim 500 \mathrm{~m}$ of the Kermadec forearc, arc front and Havre Trough backarc ${ }^{15,28,29}$. The plateau hosts $\leq 2,900 \mathrm{~m}$ 
high ridge-like seamounts and guyots with basal diameters $\leq 25 \mathrm{~km}$. Two-dimensional gravity modelling and estimates from active seismic source refraction studies suggests a Hikurangi Plateau crustal thickness of $15-23 \mathrm{~km}$ compared with a $4-6 \mathrm{~km}$ thick Pacific oceanic crust to the north ${ }^{18,30,31}$. Both these techniques assume that the mantle is marked by either $\mathrm{Vp}$ seismic velocities $>8 \mathrm{~km} \mathrm{~s}^{-1}$ or densities $>3.0 \times 10^{3} \mathrm{~kg} \mathrm{~m}^{-3}$. Reyners et al. ${ }^{20}$ however identified a seismically active $35-\mathrm{km}$ thick layer beneath the upper surface of the subducting Hikurangi Plateau. The presence of $>8.5 \mathrm{~km} \mathrm{~s}^{-1}$ velocities at the base of the seismically active zone led Reyners et al. ${ }^{20}$ to propose an eclogite layer to the plateau 'crust', doubling the thickness modelled by Davy et al. ${ }^{18}$ and Scherwarth et al. ${ }^{30}$
Geochemistry. Lava compositions from the Kermadec arc volcanoes range from basalt to rhyolite within the low- $\mathrm{K}$ tholeiitic to medium-K calcalkaline series (e.g. refs 29,32), following the rock classification by Le Maitre ${ }^{33}$ and show typical subduction zone enrichments of elements mobile in aqueous fluids (for example, $\mathrm{Rb}, \mathrm{Ba}, \mathrm{U}, \mathrm{Pb}, \mathrm{Sr}$ ) and depletions in $\mathrm{Nb}$ when compared with mid-ocean ridge basalts $\left(\mathrm{MORB}^{34}\right)$. Of all the Kermadec arc front lavas, those from the northern Kermadec arc volcanoes between 26 and $28^{\circ} \mathrm{S}$ show the least radiogenic values for $\mathrm{Pb}$ and $\mathrm{Sr}$ (for example, ${ }^{206} \mathrm{~Pb} /{ }^{204} \mathrm{~Pb}_{\text {Avg }}=18.67 ;{ }^{87} \mathrm{Sr} /{ }^{86} \mathrm{Sr}_{\text {Avg }}=0.7034$; see Table 1 for Sr-, Nd- and Pb-isotope data) and fall between Pacific MORB and sediments drilled at DSDP Site 204 (refs 24,35; Fig. 2a,c). The northern Kermadec arc lavas are also characterized

Table 1 | Sr-Nd-Pb-isotope data from selected Kermadec arc volcanic centres and the Rapuhia Scarp of the Hikurangi Plateau

\begin{tabular}{|c|c|c|c|c|c|c|c|c|c|c|}
\hline $\begin{array}{l}\text { Sample } \\
\text { number }\end{array}$ & Volcano & $\begin{array}{l}\text { Rock- } \\
\text { type }\end{array}$ & Latitude & Longitude & $\begin{array}{c}\text { Water depth } \\
\text { (m) }\end{array}$ & ${ }^{87} \mathrm{Sr} /{ }^{86} \mathrm{Sr}$ & $\begin{array}{l}{ }^{143} \mathrm{Nd} / \\
{ }^{144} \mathrm{Nd}\end{array}$ & $\begin{array}{l}{ }^{206} \mathrm{~Pb} / \\
{ }^{204} \mathrm{~Pb}\end{array}$ & $\begin{array}{c}{ }^{207} \mathrm{~Pb} / \\
{ }^{204} \mathrm{~Pb}\end{array}$ & $\begin{array}{c}{ }^{208} \mathrm{~Pb} / \\
{ }^{204} \mathrm{~Pb}\end{array}$ \\
\hline \multicolumn{11}{|c|}{ Kermadec Arc volcanic centres } \\
\hline P72388* & Hinepuia & B & $26.41^{\circ} \mathrm{S}$ & $177.28^{\circ} \mathrm{W}$ & 945 & 0.703369 & 0.513069 & 18.697 & 15.575 & 38.374 \\
\hline P72356 & Hinepuia & $A$ & $26.40^{\circ} \mathrm{S}$ & $177.25^{\circ} \mathrm{W}$ & 358 & 0.703464 & 0.513071 & 18.708 & 15.571 & 38.384 \\
\hline P72391 & Hinepuia & $D$ & $26.41^{\circ} \mathrm{S}$ & $177.28^{\circ} \mathrm{W}$ & 945 & 0.703576 & 0.513071 & 18.701 & 15.574 & 38.387 \\
\hline P72358 & Hinepuia & $D$ & $26.40^{\circ} \mathrm{S}$ & $177.25^{\circ} \mathrm{W}$ & 358 & 0.703529 & 0.513074 & 18.709 & 15.572 & 38.387 \\
\hline P72403 & Hinepuia & $\mathrm{R}$ & $26.39^{\circ} \mathrm{S}$ & $177.28^{\circ} \mathrm{W}$ & 953 & 0.703569 & 0.513066 & 18.701 & 15.570 & 38.374 \\
\hline P72360 & Hinepuia & $A$ & $26.40^{\circ} \mathrm{S}$ & $177.25^{\circ} \mathrm{W}$ & 358 & 0.703417 & 0.513054 & 18.703 & 15.573 & 38.393 \\
\hline P72404 & Hinepuia & $\mathrm{R}$ & $26.39^{\circ} \mathrm{S}$ & $177.28^{\circ} \mathrm{W}$ & 953 & 0.703418 & 0.513041 & 18.592 & 15.579 & 38.280 \\
\hline P72428 & Rakahore & $D$ & $26.81^{\circ} \mathrm{S}$ & $177.40^{\circ} \mathrm{W}$ & 1,053 & 0.703408 & 0.513121 & 18.657 & 15.573 & 38.369 \\
\hline P72442 & Rakahore & $\mathrm{R}$ & $26.84^{\circ} \mathrm{S}$ & $177.43^{\circ} \mathrm{W}$ & 690 & 0.703368 & 0.513086 & 18.690 & 15.576 & 38.393 \\
\hline P72422 & Rakahore & $D$ & $26.81^{\circ} \mathrm{S}$ & $177.41^{\circ} \mathrm{W}$ & 786 & 0.703388 & 0.513075 & 18.693 & 15.575 & 38.393 \\
\hline P72461 & Gamble & $\mathrm{R}$ & $27.21^{\circ} \mathrm{S}$ & $177.44^{\circ} \mathrm{W}$ & 328 & 0.703437 & 0.513106 & 18.661 & 15.577 & 38.381 \\
\hline P72462 & Gamble & $R$ & $27.21^{\circ} \mathrm{S}$ & $177.44^{\circ} \mathrm{W}$ & 328 & 0.703423 & 0.513116 & 18.660 & 15.577 & 38.379 \\
\hline P72448 & Gamble & $R$ & $27.20^{\circ} \mathrm{S}$ & $177.41^{\circ} \mathrm{W}$ & 620 & 0.703735 & 0.513097 & 18.654 & 15.574 & 38.368 \\
\hline P72467 & Putoto & B & $27.91^{\circ} \mathrm{S}$ & $177.61^{\circ} \mathrm{W}$ & 316 & 0.703475 & 0.513110 & 18.667 & 15.576 & 38.369 \\
\hline P72476 & Putoto & BA & $27.85^{\circ} \mathrm{S}$ & $177.61^{\circ} \mathrm{W}$ & 580 & 0.703405 & 0.513096 & 18.666 & 15.576 & 38.355 \\
\hline P72479 & Putoto & $\mathrm{D}$ & $27.85^{\circ} \mathrm{S}$ & $177.61^{\circ} \mathrm{W}$ & 580 & 0.703478 & 0.513104 & 18.660 & 15.572 & 38.348 \\
\hline P72483 & Putoto & BA & $27.85^{\circ} \mathrm{S}$ & $177.61^{\circ} \mathrm{W}$ & 580 & 0.703431 & 0.513101 & 18.661 & 15.571 & 38.350 \\
\hline P72490 & Putoto & $B$ & $27.85^{\circ} \mathrm{S}$ & $177.61^{\circ} \mathrm{W}$ & 580 & 0.703369 & 0.513093 & 18.621 & 15.566 & 38.308 \\
\hline P72495 & Hinetapeka & $\mathrm{D}$ & $28.59^{\circ} \mathrm{S}$ & $177.82^{\circ} \mathrm{W}$ & 634 & 0.703767 & 0.513064 & 18.682 & 15.571 & 38.436 \\
\hline P72498 & Hinetapeka & BA & $28.59^{\circ} \mathrm{S}$ & $177.82^{\circ} \mathrm{W}$ & 634 & 0.703742 & 0.513037 & 18.681 & 15.574 & 38.432 \\
\hline P72506 & Hinetapeka & $A$ & $28.65^{\circ} \mathrm{S}$ & $177.80^{\circ} \mathrm{W}$ & 348 & 0.703771 & 0.513068 & 18.683 & 15.572 & 38.436 \\
\hline P72511 & Hinetapeka & BA & $28.65^{\circ} \mathrm{S}$ & $177.81^{\circ} \mathrm{W}$ & 330 & 0.703776 & 0.513072 & 18.688 & 15.578 & 38.446 \\
\hline P72497 & Hinetapeka & $\mathrm{D}$ & $28.59^{\circ} \mathrm{S}$ & $177.82^{\circ} \mathrm{W}$ & 890 & 0.703744 & 0.513065 & 18.682 & 15.572 & 38.442 \\
\hline $\mathrm{T} 46-03^{\dagger}$ & Havre & $\mathrm{B}$ & $31.09^{\circ} \mathrm{S}$ & $179.06^{\circ} \mathrm{W}$ & 941 & 0.703708 & - & 18.757 & 15.597 & 38.556 \\
\hline Т 51-01 & Havre & $\mathrm{D}$ & $31.14^{\circ} \mathrm{S}$ & $179.01^{\circ} \mathrm{W}$ & 956 & 0.703707 & 0.512990 & 18.770 & 15.604 & 38.594 \\
\hline T 34-01 & Haungaroa & BA & $32.62^{\circ} \mathrm{S}$ & $179.67^{\circ} \mathrm{W}$ & 815 & 0.703909 & 0.513013 & 18.923 & 15.614 & 38.717 \\
\hline T 37-03 & Haungaroa & B & $32.60^{\circ} \mathrm{S}$ & $179.64^{\circ} \mathrm{W}$ & 1,167 & 0.703889 & 0.513031 & 18.934 & 15.617 & 38.733 \\
\hline T 27-04 & Kuiwai & BA & $33.16^{\circ} \mathrm{S}$ & $179.96^{\circ} \mathrm{W}$ & 640 & 0.703813 & - & 18.938 & 15.623 & 38.758 \\
\hline T 20-02 & Ngatoir. & BA & $33.74^{\circ} \mathrm{S}$ & $179.83^{\circ} \mathrm{E}$ & 555 & 0.703906 & 0.513057 & 18.867 & 15.616 & 38.701 \\
\hline Т 24-08 & Ngatoir. & BA & $33.75^{\circ} \mathrm{S}$ & $179.81^{\circ} \mathrm{E}$ & 1,500 & 0.703896 & 0.513140 & 18.860 & 15.611 & 38.687 \\
\hline Т 09-01 & Sonne & D & $34.07^{\circ} \mathrm{S}$ & $179.59^{\circ} \mathrm{E}$ & 1,040 & 0.703971 & 0.513012 & 18.862 & 15.632 & 38.737 \\
\hline T 88-01 & Sonne & BA & $34.02^{\circ} \mathrm{S}$ & $179.56^{\circ} \mathrm{E}$ & 1,271 & 0.703956 & - & 18.850 & 15.614 & 38.675 \\
\hline T 90-01 & Sonne & B & $34.08^{\circ} \mathrm{S}$ & $179.48^{\circ} \mathrm{E}$ & 2,405 & 0.703898 & 0.512944 & 18.848 & 15.614 & 38.672 \\
\hline Т 91-04 & Sonne & $B$ & $34.12^{\circ} \mathrm{S}$ & $179.43^{\circ} \mathrm{E}$ & 1,841 & 0.704296 & 0.512834 & 18.862 & 15.640 & 38.750 \\
\hline T 05-01 & Kibblew. & D & $34.57^{\circ} \mathrm{S}$ & $179.27^{\circ} \mathrm{E}$ & 1,174 & 0.703777 & 0.512949 & 18.832 & 15.611 & 38.638 \\
\hline T 94-02 & Kibblew. & B & $34.29^{\circ} \mathrm{S}$ & $179.24^{\circ} \mathrm{E}$ & 1,438 & 0.703246 & 0.513031 & 18.788 & 15.585 & 38.522 \\
\hline T 98-02 & Kibblew. & B & $34.69^{\circ} \mathrm{S}$ & $179.30^{\circ} \mathrm{E}$ & 1,642 & 0.703955 & 0.513012 & 18.869 & 15.607 & 38.610 \\
\hline \multicolumn{11}{|c|}{ Hikurangi Plateau } \\
\hline $34-1$ & RS & B & $35.99^{\circ} \mathrm{S}$ & $178.52^{\circ} \mathrm{W}$ & 5,918 & 0.705057 & 0.512964 & 19.171 & 15.543 & 38.384 \\
\hline $34-4^{\S}$ & RS & $B$ & $35.99^{\circ} \mathrm{S}$ & $178.52^{\circ} \mathrm{W}$ & 5,918 & 0.704586 & 0.512954 & 19.546 & 15.574 & 38.405 \\
\hline $34-11$ & RS & G & $35.99^{\circ} \mathrm{S}$ & $178.52^{\circ} \mathrm{W}$ & 5,918 & 0.704208 & 0.512945 & 19.680 & 15.550 & 38.445 \\
\hline $36-1^{\S}$ & RS & $B$ & $36.03^{\circ} \mathrm{S}$ & $178.28^{\circ} \mathrm{W}$ & 6,001 & 0.705308 & 0.512821 & 18.578 & 15.531 & 38.149 \\
\hline $36-4$ & RS & Do & $36.03^{\circ} \mathrm{S}$ & $178.28^{\circ} \mathrm{W}$ & 6,001 & 0.703742 & 0.512925 & 19.372 & 15.634 & 38.757 \\
\hline $38-1^{\S}$ & RS & B & $36.12^{\circ} \mathrm{S}$ & $178.39^{\circ} \mathrm{W}$ & 5,868 & 0.705477 & 0.512908 & 18.757 & 15.617 & 38.520 \\
\hline $38-3^{\S}$ & RS & G & $36.12^{\circ} \mathrm{S}$ & $178.39^{\circ} \mathrm{W}$ & 5,868 & 0.703924 & 0.512927 & 19.313 & 15.600 & 38.423 \\
\hline
\end{tabular}

B, Basalt; BA, Basaltic Andesite; D, Dacite; Do, Dolerite; G, Gabbro; Kibblew., Kibblewhite; Ngatoir., Ngatoirangi; R, Rhyolite.

*Samples recovered during NZAPLUME III and analysed at the University of Melbourne.

$\dagger$ Samples recovered during TANO2O5 and analysed at GEOMAR.

Samples recovered during SO168 and analysed at GEOMAR.

$\$ \mathrm{~Pb}$ double spike; values in Italics from Hoernle et al..$^{19}$ 


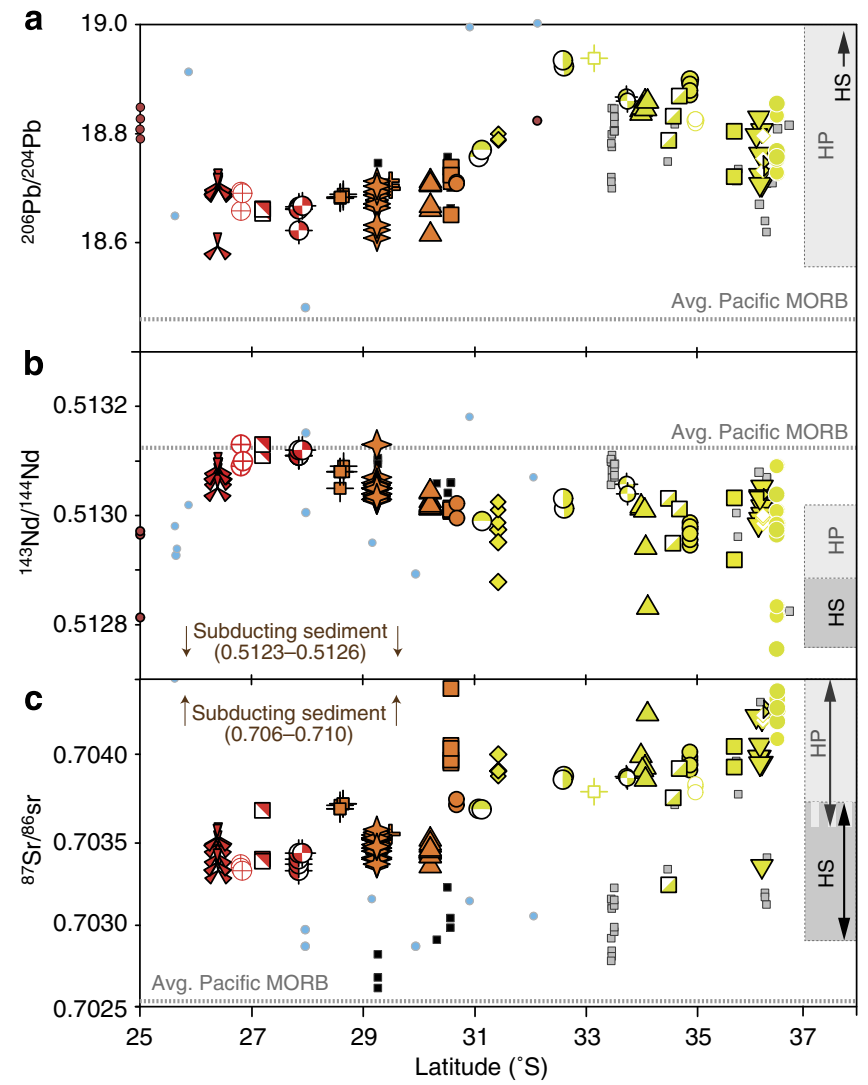

$\begin{array}{ll}\square \text { Northern Kermadec arc volcanic centres (NKA) } & \square \text { Northern Havre Trough lavas } \\ \square \text { Mid Kermadec arc volcanic centres (MKA) } & \square \text { Southern Havre Trough lavas } \\ \square \text { Southern Kermadec arc volcanic centres (SKA) } & \text { - Subducting oceanic crust } \\ & \text { - Subducting sediments }\end{array}$

Figure 2 | Isotopic changes with latitude. Latitude (in ${ }^{\circ} \mathrm{S}$ ) versus (a) ${ }^{206} \mathrm{~Pb} /{ }^{204} \mathrm{~Pb}$, (b) ${ }^{143} \mathrm{Nd} /{ }^{144} \mathrm{Nd}$, (c) ${ }^{87} \mathrm{Sr} /{ }^{86} \mathrm{Sr}$. Yellow symbols mark analyses from southern Kermadec arc (SKA) lavas. Orange symbols represent mid Kermadec arc (MKA) lava analyses and red symbols represent northern Kermadec arc (NKA) lava analyses. HP, Hikurangi Plateau and HS, Hikurangi seamounts (data range as in refs 17,19 and this study). Average (avg.) Pacific MORB data are from ref. 55 and references therein. Published Kermadec arc lava data are from refs 24,34-37,56-60. Subducting sediment data are taken from refs $24,35,36,56$. Altered oceanic crust data are from refs 61,62 . As discussed in ref. 63, the Pb-isotope data set as in ref. 24 were affected by analytical artefacts leading to lower ${ }^{206} \mathrm{~Pb} /{ }^{204} \mathrm{~Pb}$ values outside of the analytical error compared with new analyses on the same samples, and thus were omitted in this compilation.

by Pacific MORB-like (most radiogenic) $\mathrm{Nd}$ isotopic compositions $\left({ }^{143} \mathrm{Nd} /{ }^{144} \mathrm{Nd}_{A v g}=0.5131\right.$; Fig. 2b). A noticeable increase in average $\mathrm{Pb}$ and $\mathrm{Sr}$ isotopic composition to ${ }^{206} \mathrm{~Pb} /{ }^{204} \mathrm{~Pb}_{A v g}=18.69$ and ${ }^{87} \mathrm{Sr} /{ }^{86} \mathrm{Sr}_{A v g}=0.7036$, and $\mathrm{a}$ decrease in ${ }^{143} \mathrm{Nd} /{ }^{144} \mathrm{Nd}_{A v g}$ to 0.51304 , is shown by lavas erupted on the Kermadec Ridge. At $\sim 32^{\circ} \mathrm{S}$, the arc front lava $\mathrm{Pb}$ and $\mathrm{Sr}$ isotopic compositions become significantly more radiogenic, yet $\mathrm{Nd}$ isotope ratios become less radiogenic (for example, ${ }^{206} \mathrm{~Pb} /{ }^{204} \mathrm{~Pb}_{\text {Avg }}=18.84 ;{ }^{87} \mathrm{Sr} /{ }^{86} \mathrm{Sr}_{A v g}=0.7039 ;{ }^{143} \mathrm{Nd} /$ $\left.{ }^{144} \mathrm{Nd}_{A v g}=0.512987\right)$. South of $\sim 35^{\circ} \mathrm{S}$ above the presently subducting Hikurangi Plateau, the average Pb-isotope composition is variable but on average slightly less radiogenic than in lavas from adjacent volcanoes further north (for example, $\left.{ }^{206} \mathrm{~Pb} /{ }^{204} \mathrm{~Pb}_{\text {Avg }}=18.77\right)$, together with slightly higher $\mathrm{Sr}$ $\left({ }^{87} \mathrm{Sr} /{ }^{86} \mathrm{Sr}_{\text {Avg }}=0.7042\right)$ and $\mathrm{Nd}$ isotope ratios ${ }^{143} \mathrm{Nd} /$ ${ }^{144} \mathrm{Nd}_{\text {Avg }}=0.512988$; Fig. 2).

\section{Discussion}

Most lavas from the Kermadec arc volcanic centres show MORBlike less fluid mobile and conservative trace element ratios, but generally high element ratios tracing slab-derived fluids (La/ $\mathrm{Yb}<1 ; \mathrm{Ba} / \mathrm{Th}<1,200 ;$ refs 24,34). The $\mathrm{Sr}$ and $\mathrm{Pb}$ isotopic composition of the northern Kermadec arc lavas have previously been interpreted to show the effects of a MORB-type mantle wedge with the addition of $\sim 1-4 \%$ subducted sedimentand altered oceanic crust-derived, fluid-transported isotope signature. Conversely, mantle wedge heterogeneity has been proposed to explain the variations in much less fluid-mobile $\mathrm{Nd}$ isotope ratios in northern and southern Kermadec arc lavas $34,36-$ 38. The generally elevated $\mathrm{Sr}$ and $\mathrm{Pb}$, and slightly lower $\mathrm{Nd}$ isotope ratios in lavas from mid Kermadec arc volcanic centres located on the Kermadec Ridge have been attributed to (1) the interaction of ascending magmas with older Kermadec Ridge crust with higher $\mathrm{Pb}$ and $\mathrm{Sr}$, but lower $\mathrm{Nd}$ isotopic values compared with the Havre Trough backarc crust ${ }^{35,37}$ and (2) the input of slab-derived fluids carrying more radiogenic $\mathrm{Pb}$ and $\mathrm{Sr}$ isotope signatures ${ }^{34}$. Despite their emplacement behind the Kermadec Ridge on Havre Trough backarc crust, the southern Kermadec arc lavas also show elevated $\mathrm{Pb}$ and $\mathrm{Sr}$, and low $\mathrm{Nd}$ isotopic compositions suggesting an isotopically enriched source beneath these volcanoes. Previously, the increase in $\mathrm{Pb}$ and $\mathrm{Sr}$ isotope ratios in the southern Kermadec arc lavas were considered to be the result of radiogenic New Zealand-derived terrigenous sediment subduction ${ }^{37}$. However, some lavas between $\sim 32-35^{\circ} \mathrm{S}$ show higher ${ }^{206} \mathrm{~Pb} /{ }^{204} \mathrm{~Pb}$ values than local subducting sediment $\mathrm{Pb}$-isotope compositions (Figs $2 \mathrm{a}$ and $3 \mathrm{c}, \mathrm{d}$ ), requiring an additional high value ${ }^{206} \mathrm{~Pb} /{ }^{204} \mathrm{~Pb}$ component contributing to the arc lava geochemical compositions. One possible endmember is the nearby subducting Hikurangi Plateau with its large HIMUtype (HIMU = high-time integrated $\mathrm{U} / \mathrm{Pb}$ ratio) seamounts ( $c f$. refs 17,19). Exposure of the $\sim 1-\mathrm{km}$ high Rapuhia Scarp (and deep reaching faults on the Hikurangi Plateau ${ }^{18}$ ) and $\mathrm{a} \geq 1.5 \mathrm{-km}$ thick layer of sediments/volcaniclastics to seawater alteration for $\sim 120$ Myr suggests that parts of the Hikurangi Plateau are more $\mathrm{H}_{2} \mathrm{O}$-rich than 'normal' altered oceanic crust (supported by high and variable contents of large ion lithophile elements ${ }^{17,19}$ ).

However, if projected beneath the arc, the Rapuhia Scarp subducts approximately beneath the Kibblewhite volcanic centre ( $\sim 34.2^{\circ} \mathrm{S}$; Fig. 1). Subduction of an $\mathrm{H}_{2} \mathrm{O}$-rich, buoyant and thus shallow dipping Hikurangi slab $\left(\sim 20^{\circ}\right.$ to $\sim 60 \mathrm{~km}$ depth$\left.^{39}\right)$ is consistent with $\sim 500 \mathrm{~m}$ shallowing of the bathymetry, suggesting crustal uplift directly north of Kibblewhite ( $c f$. ref. 15). A more buoyant slab, which hosts bathymetric anomalies (such as LIPs) reducing the overall slab density and thus leading to shallow subduction, has also been predicted by numerical models ${ }^{40}$. The colocated change of the arc lava isotope composition, forearc subsidence, arc front offset into the backarc and deepening seafloor morphology together indicate that the initial Hikurangi Plateau-arc collision could have occurred $\sim 250 \mathrm{~km}$ further north near $\sim 32^{\circ} \mathrm{S}$ (refs 15,27 ).

Supporting evidence for initial Hikurangi subduction $\sim 250 \mathrm{~km}$ further north comes from a satellite-derived Bouguer gravity anomaly of up to $\sim 360 \mathrm{mGal}$ between $32^{\circ} \mathrm{S}$ and $34.5^{\circ} \mathrm{S}$, compared with a regional value of $\sim 240 \mathrm{mGal}$ north and south of the anomaly (Fig. 4a), suggesting shallow mantle, or dense mid-lower crust, occurs beneath this region. Two-dimensional gravity modelling along a transect parallel to the Kermadec arc front, from $\sim 30^{\circ} \mathrm{S}$ to $\sim 35.2^{\circ} \mathrm{S}$, indicates maximum crustal thinning at $\sim 32.5^{\circ} \mathrm{S}$, gradually thickening both to the north and south from this point. This region of crustal thinning coincides with deeper (by $\leq 500 \mathrm{~m}$ ) bathymetry (Figs 1 and $4 \mathrm{~b}$ ). The subduction of major ridges or seamounts is one of the most effective mechanisms to increase tectonic erosion ${ }^{41}$. We can therefore 


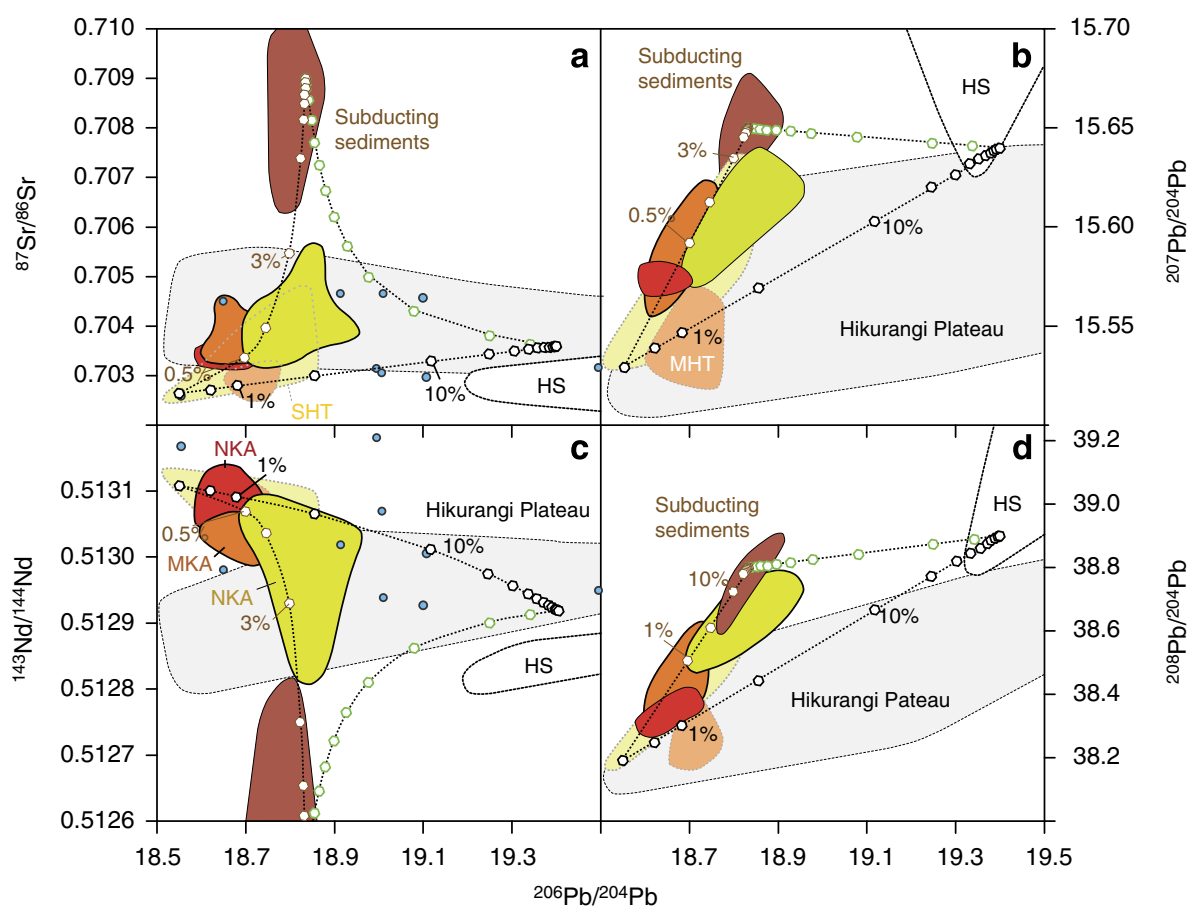

Figure 3 | Kermadec arc Isotopic variation. ${ }^{206} \mathrm{~Pb} /{ }^{204} \mathrm{~Pb}$ versus a) ${ }^{87} \mathrm{Sr} /{ }^{86} \mathrm{Sr}$, b) $\left.{ }^{207} \mathrm{~Pb} /{ }^{204} \mathrm{~Pb}, \mathrm{c}\right){ }^{143} \mathrm{Nd} /{ }^{144} \mathrm{Nd}$ and d) ${ }^{208} \mathrm{~Pb} /{ }^{204} \mathrm{~Pb}$. Fields shown are for NKA (red), MKA (orange) and SKA (yellow), subducted sediments (red-brown), Hikurangi Plateau (HP; grey) and Hikurangi seamounts (HS; white); MHT, mid Havre Trough; SHT, southern Havre Trough. Dashed lines with hexagons are mixing calculations between; (1) depleted mantle wedge and subducted sediments, (2) depleted mantle wedge and Hikurangi Plateau (consisting of $90 \%$ average Hikurangi Plateau basement and 10\% average Hikurangi seamounts) and (3) subducted sediments and Hikurangi Plateau. See Supplementary Table 1 for modelling details. Hikurangi Plateau and seamount data are from refs 17,19 , and this study.

assume that the subduction of thickened plateau crust, hosting large seamounts, will significantly increase the rate of tectonic erosion. Much of the margin collapse following removal of plateau support accompanying southward migration of the plateau subduction interface will also enhance effective tectonic erosion ${ }^{27}$. These effects will cause crustal thinning in addition to normal tectonic erosion resulting in the formation of a thick subduction channel mélange at the slab-mantle wedge interface. The apparent increase in crustal thickness towards the south from c. $32.5^{\circ}$, implied by the two-dimensional gravity model ( $c f$. Fig. 4), is likely instead to be partly attributable to dynamic support of the margin (particularly south of $34^{\circ}$ ) by the subducting buoyant Hikurangi Plateau. Moving southward there is a gradual decrease in the spacing of volcanic edifices along-strike, from one edifice every $\sim 55 \mathrm{~km}$ north of $\sim 32^{\circ} \mathrm{S}$, to one edifice every $\sim 45 \mathrm{~km}$ between $\sim 32^{\circ}$ to $35^{\circ} \mathrm{S}$ and finally to one edifice every $\sim 30 \mathrm{~km}$ south of $35^{\circ} \mathrm{S}$ above the present-day subducting Hikurangi Plateau (cf. ref. 15). This decrease in spacing between volcanic centres is accompanied by an increase in the total volume of lava erupted onto the seafloor from $\sim 830 \mathrm{~km}^{3}$ between $34^{\circ} \mathrm{S}$ and $32^{\circ} \mathrm{S}$ to $\sim 1,200 \mathrm{~km}^{3}$ between $\sim 35^{\circ} \mathrm{S}$ and $37^{\circ} \mathrm{S}$ (ref. 29), suggesting not only a relation between Hikurangi Plateau subduction and enhanced magma production, but also an impact on the stress field. That is, enhanced fracturing of the overlying plate, creating relatively more zones of weakness, such as faults in the crust along which magmas are channelled and can rise towards the surface. Dehydration of 15-23-km thick and more $\mathrm{H}_{2} \mathrm{O}$-rich Hikurangi crust will significantly increase the fluid flux from the subducting plate, thus forming a more hydrated overlying mantle wedge than to the north.

Erosion of thickened Hikurangi crust and seamounts and subducted sediments will create a buoyant, $\mathrm{H}_{2} \mathrm{O}$-rich 'Hikurangi mélange', containing a mixture of Hikurangi Plateau basement and seamount material embedded in a metasedimentary matrix including fragments of the overlying crust (cf. Fig. 5). Using a Hikurangi Plateau isotopic composition of ${ }^{206} \mathrm{~Pb} / 204 \mathrm{~Pb}=19.35$; ${ }^{207} \mathrm{~Pb} / 204 \mathrm{~Pb}=15.62 ;{ }^{208} \mathrm{~Pb} /{ }^{204} \mathrm{~Pb}=38.74 ;{ }^{87} \mathrm{Sr} /{ }^{86} \mathrm{Sr}=0.7037$ and ${ }^{143} \mathrm{Nd} /{ }^{144} \mathrm{Nd}=0.51295$ (see Fig. 3 caption for details), the $\mathrm{Pb}$ and $\mathrm{Sr}$ isotope signatures in lavas from volcanoes located between $\sim 32$ and $35^{\circ} \mathrm{S}$ can be explained by mixing depleted mantle wedge melts with $\sim 3-10 \%$ of subducted sediment and $\sim 20-55 \%$ Hikurangi components (Fig. 3). Given that the Kermadec arc is one of the oldest and coldest subduction zones globally with an estimated slab surface temperature of $\sim 745-760^{\circ} \mathrm{C}$ beneath $\sim 30.2$ to $37.9^{\circ} \mathrm{S}$ (refs 37,42 ), it is unlikely that significant slab melting will occur. Therefore, although $\mathrm{Pb}$ and $\mathrm{Sr}$ are mobile in aqueous fluids, the decrease in ${ }^{143} \mathrm{Nd} /{ }^{144} \mathrm{Nd}$ values cannot be explained through a subducting slab-derived fluid flux alone (due to low $\mathrm{Nd}$ mobility in aqueous fluids at temperatures $\leq 800^{\circ}$ (at $4 \mathrm{GPa}$; ref. 43). Previously, variations in trace element ratios and isotope compositions of rather conservative elements in southern Kermadec arc lavas were attributed to ambient mantle heterogeneity predating the geochemical imprint of the subducting $\mathrm{slab}^{36}$. Although ambient mantle wedge heterogeneities (and/or the involvement of deep crustal or lithospheric mantle fragments of rifted Gondwana continental material) could account for the observed isotopic Kermadec arc lava heterogeneities, the simultaneous increase in $\mathrm{Pb}$ and $\mathrm{Sr}$ but decrease in $\mathrm{Nd}$ isotope values, together with the aforementioned observations, plausibly argues for Hikurangi Plateau subduction-related processes causing the observed isotopic changes south of $\sim 32^{\circ} \mathrm{S}$. A similar input of an OIB-type slab signature, including a positive gravity anomaly (GH2; Fig. 4a) can be observed further north, where the subduction of the Louisville Seamount Chain affects the central Tonga-Kermadec $\operatorname{arc}^{14}$. 
a

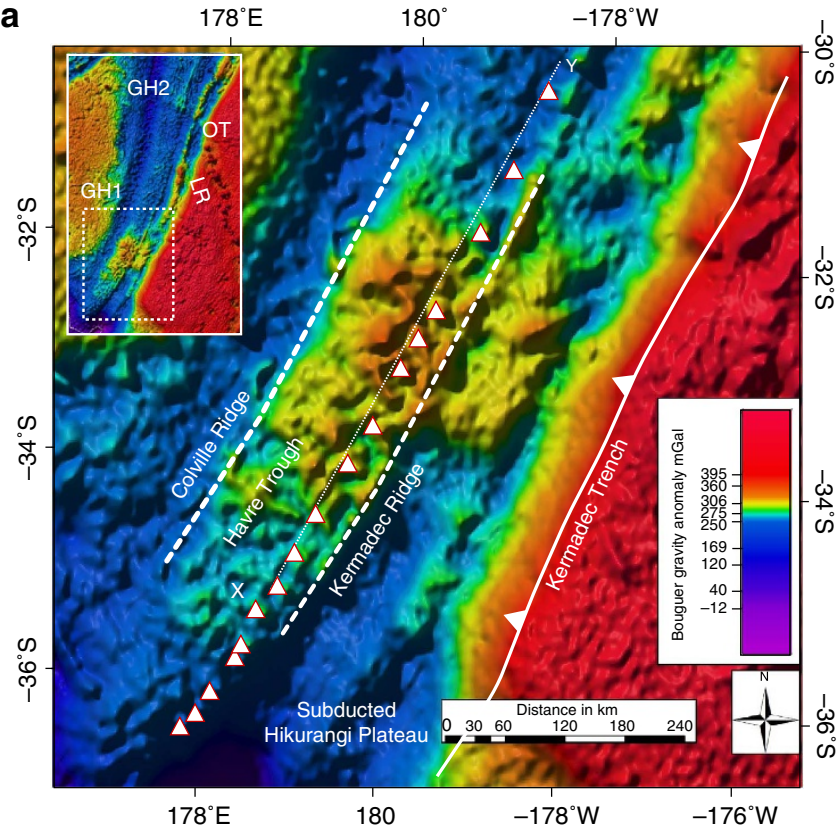

b

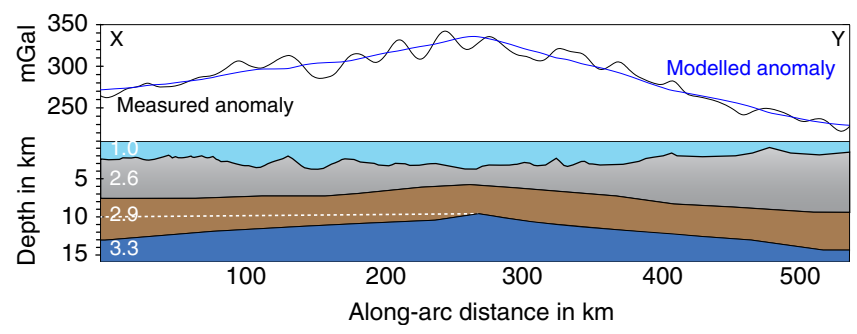

Figure 4 | Bouguer gravity anomaly map and two-dimensional gravity model along the Kermadec arc front. (a) Satellite-altimetry-derived Bouguer gravity anomaly map of the Kermadec arc system between $\sim 30^{\circ} \mathrm{S}$ and $\sim 36.5^{\circ} \mathrm{S}$. Bouguer gravity anomaly is calculated using free air gravity anomaly (ref. 64, version 18) plus NIWA bathymetry ${ }^{65}$ and a $2.67 \times 10^{3} \mathrm{~kg} \mathrm{~m}^{-3}$ density for the water body. Upper left corner inset shows the Bouguer gravity anomaly for the entire arc. Triangles mark the location of the arc front volcanic centres. White dashed line marks the location of the along-arc profile shown in Fig. $4 \mathrm{~b}$ with $\mathrm{X}$ and $\mathrm{Y}$ being the start and end points. $\mathrm{GH} 1$, gravity high 1; GH2, gravity high 2 (located where the Louisville seamount chain subducts); LSC, Louisville seamount chain; OT, Osbourn trough. (b) Two-dimensional gravity model along the Kermadec arc front. Dark blue represents the upper mantle overlain by lower crust (brown), upper crust (grey) and seawater (light blue). White numbers are densities in $\mathrm{g} \mathrm{cm}^{-3}$. White dashed line within the lower crust marks hypothetical crustal thickness, assuming the addition of dynamic support of the crust from the buoyant Hikurangi Plateau.

Tomography results from a trench-perpendicular ocean bottom seismometer array oriented east-west across the Kermadec trench to the Havre Trough at $\sim 37^{\circ} \mathrm{S}$ (refs 30,31 ) show zones of reduced seismic velocities (that is, Vp $\leq 7.8 \mathrm{~km} \mathrm{~s}^{-1}$ compared with $\geq 8 \mathrm{~km} \mathrm{~s}^{-1}$ for mantle peridotite) beneath the arc front $\mathrm{MOHO}$, consistent with $\geq 10 \%$ of serpentenized mantle being present beneath the $\operatorname{arc}^{44}$. A similar $\sim 10-\mathrm{km}$ thick crust-mantle transition layer with lower seismic velocities (that is, $\mathrm{Vp}=7.0-7.7 \mathrm{~m} \mathrm{~s}^{-1}$ ) has also been identified beneath the Izu-Bonin-Mariana and Tonga arcs, interpreted to be composed of a mixture of crustal and mantle materials ${ }^{45,46}$. Likewise, beneath the central Taupo Volcanic Zone, a zone of reduced seismic velocities of $\geq \mathrm{Vp}=7.4 \mathrm{~m} \mathrm{~s}^{-1}(\mathrm{Vp} / \mathrm{Vs}=\sim 1.87)$

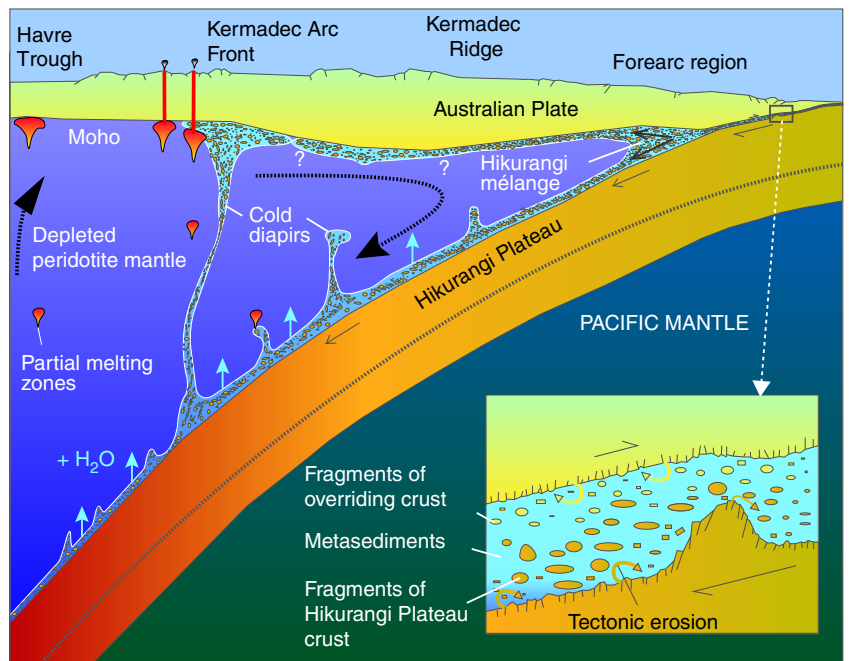

Figure 5 | Schematic across-arc section. Section illustrating the effect of the subducting Hikurangi Plateau on processes in the mantle and crust beneath the southern Kermadec arc. Increased tectonic erosion in the forearc regions creates a thick, $\mathrm{H}_{2} \mathrm{O}$-rich mélange layer, containing fragments of the overriding forearc crust and more importantly of the subducting Hikurangi Plateau in a metasedimentary matrix. The Hikurangi mélange is subducted to deeper depth, where due to its buoyant behaviour forms cold diapirs, which rise through mantle wedge and eventually pond beneath a density barrier, such as the Moho. Because of the dehydration of the subducting plate during its descent, the arc lavas may already contain a fluid-derived (mostly Pb and less significant $\mathrm{Sr}$ ) Hikurangi Plateau signature. Interaction of melts with the Hikurangi mélange layer at the Moho can also explain the large-scale variation of ${ }^{143} \mathrm{Nd} /{ }^{144} \mathrm{Nd}$ isotope values not only above the presently subducting Hikurangi Plateau, but also to the north, where the Kermadec arc crust has been underplated in the past. Local variations in lava $\mathrm{Sr}-, \mathrm{Nd}$ - and $\mathrm{Pb}$-isotope composition may indicate that the Hikurangi mélange does not form a continuous layer beneath the Moho and may only occur locally consistent with its formation through cold diapirs.

extends from the Moho to the slab-mantle wedge interface suggesting diapirically rising hydrated and low density material $^{49}$. Lower seismic velocities of $\mathrm{Vp}=\sim 7.7$, (and density $=\sim 3.0 \mathrm{~g} \mathrm{~cm}^{-3} ; \mathrm{Vp} / \mathrm{Vs}=\sim 1.85$ ), which are similar to the velocities observed at the crust-mantle boundary beneath arcs have been measured in exhumed subduction mélange rocks with compositions intermediate between chlorite schists and jadeite (at $\mathrm{T}=600^{\circ} \mathrm{C}$ and $\mathrm{P}=2 \mathrm{GPa}$ ). Numerical modelling results show that buoyant cold diapir formation requires $\sim 1-10-\mathrm{km}$ thick mélange layers at the slab surface-mantle wedge interface (refs 48,49 and references therein). The formation of a more hydrated Hikurangi mélange above the subducting plateau than beneath the northern Kermadec arc will reduce the mélange density. This, in turn, is likely to create more diapirs rising through mantle wedge and to partially melt via decompression (Fig. 5). The formation of volatile-rich melts above the subducting Hikurangi Plateau can therefore explain the higher volcano density and possibly the formation of large silicic magma chambers beneath the Taupo Volcanic Zone on the North Island of New Zealand (cf. ref. 50). The thin crust between 32 and $34.5^{\circ} \mathrm{S}$ coincides with the occurrence of large volcanoes, lavas from which show the highest $\mathrm{Pb}$ isotopic values, suggesting a high percentage of a Hikurangi component in the mélange formed through increased tectonic erosion during early Hikurangi Plateau subduction. The increasing crustal thickness, ${ }^{87} \mathrm{Sr} /{ }^{86} \mathrm{Sr}$ and ${ }^{143} \mathrm{Nd} /{ }^{144} \mathrm{Nd}$ values but general decrease of ${ }^{206} \mathrm{~Pb} /{ }^{204} \mathrm{~Pb}$ south 


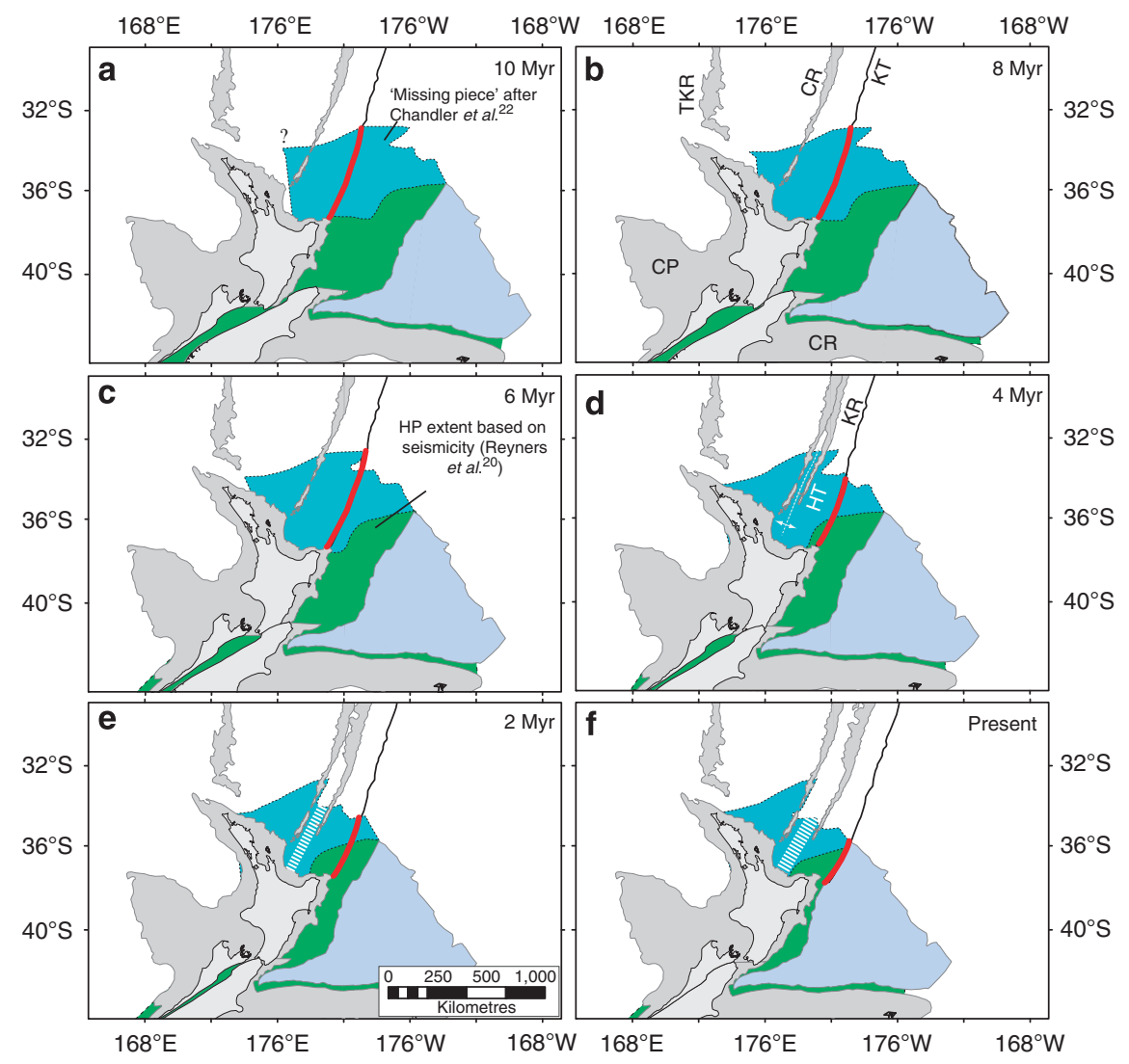

Figure 6 | GPlates-based reconstruction of Pacific and Australian plates NE of New Zealand. Pacific and Australian Plate (Australian Plate fixed and rigid; Kermadec trench fixed) convergence along the Kermadec arc segment are shown in 2 Myr steps from 10 Myr (a) to present (f) using finite rotations from refs 5,66. CP, Challenger Plateau; CR, Chatham Rise; CR, Colville Ridge; HT, Havre Trough; KR, Kermadec Ridge; TKR, Three Kings Ridge. Dark grey areas represent seafloor above $\sim 2,000$ m.b.s.l. Red line in each panel indicates the length of Kermadec Trench beneath which Hikurangi Plateau is subducting. Dashed white line marks the Havre Trough. Present extent of the Hikurangi Plateau (light blue shading), present subducted extent derived from seismic tomography and earthquake hypocentres ${ }^{20}$ (green shading), and 'missing piece' of Ontong Java Nui (dark blue shading) from ref. 22. The reconstruction was conducted using GPlates software available at http://www.gplates.org/.

of $\sim 35^{\circ} \mathrm{S}$ indicates the increasing contribution of a sedimentary component gradually diluting the Hikurangi signature.

We conclude that a geochemically heterogeneous Hikurangi mélange layer, assimilated by younger ascending, or stagnated Kermadec arc melts, can explain the observed change in arc lava geochemical compositions of the southern Kermadec arc lavas. On the basis of isotopic, bathymetric and gravity variations along the Kermadec arc, the initial arc-Hikurangi Plateau collision can be identified at least $250 \mathrm{~km}$ north of its present location, suggesting that a much larger portion of the plateau than previously estimated has been subducted since $>10 \mathrm{Myr}$ (Fig. 6). The extent of the gap of the Ontong Java Nui super plateau ${ }^{22}$ and of the subducted Hikurangi Plateau portion (inferred by geochemistry, morphology and gravity; Fig. 5) suggests that we may have identified the missing piece of this super plateau. Furthermore, we have demonstrated that LIP subduction has profound implications for fundamental processes occurring at oceanic arcs, such as increased rates of tectonic erosion and elevated fluid flux from the subducting slab, which in turn, influence the eruptive behaviour and possibly the style of hydrothermal systems at arc volcanoes and the element transfer into the world's oceans.

\section{Methods}

Sampling. The Kermadec arc volcanic centres between $\sim 26^{\circ} \mathrm{S}$ and $28.6^{\circ} \mathrm{S}$ (Hinepuia-Hinetapeka) and between $\sim 31^{\circ} \mathrm{S}$ and $34^{\circ} \mathrm{S}$ (Havre-Kibblewhite; Fig. 1) were mapped and sampled during the RV Tangaroa expeditions NZAPLUME III in 2004 and TAN0205 in 2005 (refs 26,33). Additional samples from the Hikurangi Plateau (Rapuhia Scarp) were recovered during the R/V Sonne expedition SO168 Zealandia in $2002 / 2003$.

Isotope analyses. For chemical analysis fresh cores of the samples were extracted, repeatedly washed in deionized water (in an ultrasonic bath) to remove sea salt, then crushed, handpicked and reduced to powder in an agate mill. Isotope analyses were conducted at the University of Melbourne and GEOMAR. At the University of Melbourne between 50 and $100 \mathrm{mg}$ of fresh, clean chips 1-5 mm in diameter were handpicked for isotopic analysis and then leached in hot $6 \mathrm{~N} \mathrm{HCl}$ for $30 \mathrm{~min}$ to remove any contaminants. Samples were then washed in ultrapure water and dissolved in $\mathrm{HF} / \mathrm{HNO}_{3}$ acid mixtures. Separation of $\mathrm{Pb}, \mathrm{Sr}$ and $\mathrm{Nd}$ involved standard ion exchange procedures using Eichron ion specific resins. Analytical blanks are in all cases insignificant relative to the amount of sample processed and no blank corrections were made. Separated $\mathrm{Sr}, \mathrm{Nd}$, and $\mathrm{Pb}$ were run on a $\mathrm{Nu}$ Instruments MC-ICPMS coupled to a CETAC Aridus desolvating nebulizer operating at a sample uptake rate of $\sim 60 \mu 1 \mathrm{~min}^{-1}$. Instrumental mass bias was corrected using an exponential bias law with ${ }^{87} \mathrm{Sr} /{ }^{86} \mathrm{Sr}$ normalized to ${ }^{86} \mathrm{Sr} /$ ${ }^{88} \mathrm{Sr}=0.1194$ and reported relative to NIST SRM $987=0.710250$. For Sr-isotopes, internal precision is typically $<0.000015$ ( 2 s.e.) with reproducibility ( 2 s.d. of repeat runs) $\leq \pm 0.000040 .{ }^{143} \mathrm{Nd} /{ }^{144} \mathrm{Nd}$ was normalized to ${ }^{146} \mathrm{Nd} /$

${ }^{145} \mathrm{Nd}=2.0719425$ (equivalent to ${ }^{146} \mathrm{Nd} /{ }^{144} \mathrm{Nd}=0.7219$ ) and reported relative to La Jolla Nd reference material $=0.511865$. Internal precision is typically $<0.000010$ (2 s.e.) with reproducibility ( 2 s.d. of repeat runs) $\leq \pm 0.000020$. Pbisotope ratios are reported relative to SRM 981 values of $16.935,15.489,36.701$ with reproducibility ( 2 s.d. of repeat runs) $\leq \pm 0.03 \%$. See refs 51,52 for $\mathrm{Pb}$ and $\mathrm{Sr}-\mathrm{Nd}$ procedures, respectively.

At GEOMAR, leached whole rock powders $\left(6 \mathrm{~N} \mathrm{HCl}\right.$ at $130^{\circ} \mathrm{C}$ for $\left.1 \mathrm{~h}\right)$ were used for Sr, $\mathrm{Nd}$ chemistry and leached rock chips $(2 \mathrm{~N} \mathrm{HCl}$ at room temperature for $30 \mathrm{~min}$ ) for $\mathrm{Pb}$. Sample dissolution involved $4 \mathrm{ml}$ conc. $\mathrm{Hf}$ and $1.5 \mathrm{ml} \mathrm{HNO}_{3}$ at $150^{\circ} \mathrm{C}$ for $48 \mathrm{~h}$ in a closed teflon vial, followed by evaporation to dryness, uptake in $6 \mathrm{~N} \mathrm{HCl}$ and final evaporation to dryness. The element chromatography followed 
established standard procedures ${ }^{53}$. Isotopic ratios were analysed in static multicollection mode on a TRITON (Nd) and MAT262 $\mathrm{RPQ}^{2+}(\mathrm{Sr}-\mathrm{Pb})$ thermal ionization mass spectrometers. $\mathrm{Sr}$ and $\mathrm{Nd}$ isotopic ratios are normalized within run to ${ }^{86} \mathrm{Sr} /{ }^{88} \mathrm{Sr}=0.1194$ and ${ }^{146} \mathrm{Nd} /{ }^{144} \mathrm{Nd}=0.7219$, respectively and isotope data reported relative to $\mathrm{NBS} 987^{87} \mathrm{Sr} /{ }^{86} \mathrm{Sr}=0.710250 \pm 0.000012$ (2 s.d., $N=20$ ) and ${ }^{143} \mathrm{Nd} /{ }^{144} \mathrm{Nd}=0.511850 \pm 0.000005$ ( 2 s.d., $N=27$ ) for La Jolla. NBS981 gave ${ }^{206} \mathrm{~Pb} /{ }^{204} \mathrm{~Pb}=16.898 \pm 0.006,{ }^{207} \mathrm{~Pb} /{ }^{204} \mathrm{~Pb}=15.437 \pm 0.007,{ }^{208} \mathrm{~Pb} /$

${ }^{204} \mathrm{~Pb}=36.527 \pm 0.024$ ( 2 s.d., $\left.N=125 ; 2003-2006\right)$ and were corrected for mass bias to our NBS981 double spike values of ${ }^{206} \mathrm{~Pb} /{ }^{204} \mathrm{~Pb}=16.9412 \pm 0.0021,{ }^{207} \mathrm{~Pb} /$ ${ }^{204} \mathrm{~Pb}=15.4992 \pm 0.0020,{ }^{208} \mathrm{~Pb} /{ }^{204} \mathrm{~Pb}=36.7225 \pm 0.0049$ (2 s.d., $N=69 ; 2006-$ 2008). This external mass bias procedure applies to samples $34-11$ and $36-4$ while the remaining samples were mass bias corrected by $\mathrm{Pb}$ double spike ${ }^{54}$. Total chemistry were $<100 \mathrm{ng} \mathrm{Sr}-\mathrm{Nd}-\mathrm{Pb}$ and thus considered neglible relative to the amount of sample.

\section{References}

1. Self, S., Jay, A. E., Woddowson, M. \& Keszthelyi, L. P. Correlation of the Deccan and Rajahmundry trap lavas: are these the longest and largest lava flows on earth? J. Volcanol. Geoth. Res. 99, 24,275-24,300 (2008).

2. Ben-Avraham, Z., Nur, A., Jomes, D. \& Cox, A. Continental accretion: from oceanic plateaus to allochtonous terranes. Science 213, 47-54 (1981).

3. Coffin, M. F. \& Eldholm, O. Large igneous provinces: crustal structure, dimensions, and external consequences. Rev. Geophys. 32, 1-36 (1994).

4. Kerr, A. in Treatise of Geochemistry (eds Holland, H. \& Turekian, K.) 2nd edn, Vol. 4 The Crust (Elsevier, Amsterdam 631-667, 2014).

5. Yan, C. \& Kroenke, L. in Proc. Ocean Drilling Program Scient. Results 130, 697-709 (Ocean Drilling Program, College Station, TX, 1993).

6. Van der Hilst, R. \& Mann, P. Tectonic implications of tomographic images of subducted lithosphere beneath northwestern South America. Geology 22, 451-454 (1994).

7. Mann, P. \& Taira, A. Global tectonic significance of the Solomon Islands and Ontong Java Plateau convergent zone. Tectonophysics 389, 137-190 (2004).

8. Hastie, A. R. et al. Do Cenozoic analogues support a plate tectonic origin for the Earth's earliest continental crust? Geology 38, 495-498 (2010).

9. de Wit, M. J. et al. Formation of an Archean continent. Nature 357, 553-562 (1992).

10. Pearce, J. A. \& Peate, D. W. Tectonic implications of the composition of volcanic arc magmas. Annu. Rev. Earth Planet. Sci. 23, 251-285 (1995).

11. Elliott, T., Plank, T., Zindler, A., White, W. \& Bourdon, B. Element transport from slab to volcanic front at the Mariana arc. J. Geophys. Res. 102, 14991-15019 (1997).

12. Stern, R. J. Subduction zones. Rev. Geophys. 40, 1012 (2002).

13. Hoernle, K. A. et al. Arc-parallel flow in the mantle wedge beneath Costa Rica and Nicaragua. Nature 451, 1094-1098 (2008).

14. Timm, C. et al. Louisville seamount subduction and its implication on mantle flow beneath the central Tonga-Kermadec arc. Nat. Commun. 4, 1720 (2013).

15. de Ronde, C. E. J. et al. Submarine hydrothermal activity along the midKermadec Arc, New Zealand: large-scale effects on venting. Geochem. Geophys. Geosys. 8, Q07007 (2007).

16. Davy, B. \& Wood, R. Gravity and magnetic modelling of the Hikurangi Plateau. Mar. Geol. 118, 139-151 (1994).

17. Mortimer, N. \& Parkinson, D. Hikurangi Plateau: a large igneous province in the southwest Pacific Ocean. J. Geophys. Res. 101, 687-696 (1996).

18. Davy, B., Hoernle, K. \& Werner, R. Hikurangi Plateau: Crustal structure, rifted formation, and Gondwana subduction history. Geochem. Geophys. Geosys. 9, Q07004 (2008).

19. Hoernle, K. et al. Age and geochemistry of volcanic rocks from the Hikurangi and Manihiki oceanic Plateaus. Geochim. Cosmochim. Acta 74, 7196-7219 (2010).

20. Reyners, M., Eberhart-Phillips, D. \& Bannister, S. Tracking repeated subduction of the Hikurangi Plateau beneath New Zealand. Earth Planet. Sci. Lett. 311, 165-171 (2011).

21. Taylor, B. The single largest oceanic plateau: Ontong Java-ManihikiHikurangi. Earth Planet. Sci. Lett. 241, 372-380 (2006).

22. Chandler, M. T. et al. Reconstructing Ontong Java Nui: implications for Pacific absolute plate motion, hotspot drift and true polar wander. Earth Planet. Sci. Lett. 331-332, 140-151 (2012).

23. DeMets, C., Gordon, R. G., Argus, D. F. \& Stein, S. Effect of recent revisions to the geomagnetic reversal time scale and estimates of current plate motions. Geophys. Res. Lett. 21, 2191-2194 (1994).

24. Turner, S. P. et al. Uranium-238/ thorium-230 disequilibria, magma petrogenesis, and flux rates beneath the depleted Tonga-Kermadec island arc. Geochim. Cosmochim. Acta 61, 4855-4884 (1997).

25. Carter, L., Carter, R. M., McCave, I. N. \& Gamble, J. Regional sediment recycling in the abyssal Southwest Pacific Ocean. Geology 24, 735-738 (1996).

26. Collot, J.-Y. \& Davy, B. Forearc structures and tectonic regimes at the oblique subduction zone between the Hikurangi Plateau and the southern Kermadec margin. J. Geophys. Res. 103, 623-650 (1998).
27. Davy, B. \& Collot, J.-Y. The Rapuhia scarp (northern Hikurangi Plateau)-its nature and subduction effects on the Kermadec Trench. Tectonophysics 328, 269-295 (2000).

28. Collot, J.-Y. et al. From oblique subduction to intra-continental transpression: structures of the southern Hikurangi margin from multibeam bathymetry, side scan sonar and seismic reflection. Mar. Geophys. Res. 18, 357-381 (1996).

29. Wright, I. C., Worthington, T. J. \& Gamble, J. A. New multibeam mapping and geochemistry of the $30^{\circ}-35^{\circ} \mathrm{S}$ sector, and overview, of the southern Kermadec arc volcanism. J. Volcanol. Geoth. Res. 149, 263-296 (2006).

30. Scherwarth, M. et al. Fore-arc deformation at the northern Hikurangi margin, New Zealand. J. Geophys. Res. 115, B06408 (2010).

31. Bassett, D. et al. Three-dimensional velocity structure of the northern Hikurangi margin, Raukumara, New Zealand: implications for the growth of continental crust by subduction erosion and tectonic underplating. Geochem. Geophys. Geosys. 11, Q10013 (2010).

32. Graham, I. J. et al. Structure and petrology of newly discovered volcanic centers in the northern Kermadec-southern Tofua arc, South Pacific Ocean. J. Geophys. Res. B 113, B08S02 (2008).

33. Le Maitre, R. W. in Igneous Rocks: A Classification and Glossary of Terms, Recommendations of the International Union of Geological Sciences, Subcommission of the Systematics of Igneous Rocks (eds Streckeisen, A. et al.) (Cambridge Univ. Press, 2002).

34. Haase, K. M., Worthington, T. J., Stoffers, P., Garbe-Schoenberg, D. \& Wright, I. Mantle dynamics, element recycling, and magma genesis beneath the Kermadec Arc-Havre Trough. Geochem. Geophys. Geosys. 3, 1071 (2002).

35. Ewart, A., Collerson, K. D., Regelous, M., Wendt, J. I. \& Niu, Y. Geochemical evolution within the Tonga-Kermadec-Lau arc-back-arc systems; the role of varying mantle wedge composition in space and time. J. Petrol. 39, 331-368 (1998).

36. Todd, E. et al. Sources of constructional cross-chain volcanism in the southern Havre Trough: New insights from the HFSE and REE concentration and isotope systematics. Geochem. Geophys. Geosys. 11, 4 (2010).

37. Todd, E. et al. Hf isotopic evidence for small-scale heterogeneity in the mode of mantle wedge enrichment: Southern Havre Trough and South Fiji Basin back arcs. Geochem. Geophys. Geosys. 12, Q09011 (2011).

38. Timm, C., Graham, I. J., de Ronde, C. E. J., Leybourne, M. I. \& Woodhead, J. Geochemical evolution of Monowai volcanic center: New insights into the northern Kermadec arc subduction system, SW Pacific. Geochem. Geophys. Geosys. 12 Q0AF01 (2011).

39. Isacks, B. L. \& Barazangi, M. in Island Arcs Deep Sea Trenches and Back-Arc Basins: Maurice Ewing Ser (eds Taiwani, M. \& Pitman, III W. C.vol. 1 pp. 99114 (American Geophysical Union, Washington D. C., 1977).

40. Van Hunen, J., van den Berg, A. P. \& Vlaar, N. J. On the role of subducting oceanic plateaus in the development of shallow flat subduction. Tectonophysics 352, 317-333 (2002).

41. Ranero, C. R. \& von Huene, R. Subduction erosion along the Middle American convergent margin. Nature 404, 748-752 (2000).

42. Syracuse, E. M., van Keken, P. E. \& Abers, G. A. The global range of subduction zone thermal models. Phys. Earth Planet. Int. 183, 73-90 (2010).

43. Kessel, R., Schmidt, M. W., Ulmer, P. \& Pettke, T. Trace element signature of subductionzone fluids, melts and supercritical liquids at $120-180 \mathrm{~km}$ depth. Nature 437, 724-727 (2005).

44. Carlson, R. L. \& Miller, D. J. Mantle wedge water contents estimated from seismic velocities in partially serpentenized peridotites. Geophys. Res. Lett. 30, 1250 (2003).

45. Crawford, W. C., Hildebrand, J. A., Dorman, L. M., Webb, S. C. \& Wiens, D. A Tonga Ridge and Lau Basin crustal structure from seismic refraction data. J. Geophys. Res. 108, 2195 (2003).

46. Takahashi, N. et al. Structural variations of arc crusts and rifted margins in the southern Izu-Ogasawara arc-back-arc system. Geochem. Geophys. Geosys. 10, Q09X08 (2009).

47. Reyners, M., Eberhart-Phillips, Stuart, G. \& Nishimura, Y. Imaging subduction from the trench to $300 \mathrm{~km}$ depth beneath the central North Island, New Zealand, with $V p$ and $V p / V s$. Geophys. J. Int. 165, 565-583 (2006).

48. Gerya, T. V. in Intra-oceanic subduction zones (eds Brown, D. \& Ryan, P. D.) 23-51 (Arc-Continent Collision, Frontiers in Earth Sciences, 2011).

49. Marschall, H. R. \& Schumacher, J. C. Arc magmas sourced from mélange diapirs in subduction zones. Nat. Geosci. 5, 862-867 (2012).

50. Wilson, C. J. N., Gravely, D. M., Leonard, G. S. \& Rowland, J. V. in Studies in Volcanology: The legacy of George Walker Special Publications of IAVCEI (eds Thordarson et al.) Vol. 2, 225-247 (Geological Society of London, 2008).

51. Woodhead, J. D. A simple method for obtaining highly accurate Pb-isotope data by MC-ICPMS. J. Anal. Atom. Spectrom. 17, 1381-1385 (2002).

52. Hergt, J., Woodhead, J. \& Schofield, A. A-type magmatism in the Western Lachlan Fold Belt? A study of granites and rhyolites from the Grampians region, Western Victoria. Lithos 97, 122-139 (2007).

53. Hoernle, K. et al. Arc-parallel flow in the mantle wedge beneath Costa Rica and Nicaragua. Nature 451, 1094-1097 (2008). 
54. Todt, W., Cliff, R. A., Hanser, A. \& Hofmann, A. W. in Basu, A. \& Hart, S.) (eds) Earth Processes: Reading the Isotopic Code (Geophysical Monograph) (American Geophysical Unionvol 95, 429-437, 1996).

55. Meyzen, C. M. et al. Isotopic portrayal of the Earth's upper mantle flow field. Nature 444, 1069-1074 (2007).

56. Gamble, J., Woodhead, J., Wright, I. \& Smith, I. Basalt and sediment geochemistry and magma petrogenesis in a transect from oceanic island arc to rifted continental margin arc: the Kermadec-Hikurangi Margin, SW Pacific. J. Petrol. 37, 1523-1546 (1996).

57. Gamble, J. A., Christie, R. H. K., Wright, I. C. \& Wysoczanski, R. J. Primitive K-rich magmas from Clark volcano, southern Kermadec arc: a paradox in the K-depth relationship. Can. Mineral. 35, 275-290 (1997).

58. Haase, K. A., Stroncik, N., Garbe-Schoenberg, D. \& Stoffers, P. Formation of island arc dacite magmas by extreme crystal fractionation: an example from Brothers Seamount, Kermadec island arc (SW Pacific). J. Volcanol. Geoth. Res. 152, 316-330 (2006).

59. Barker, S. J. et al. Geochemistry and petrogenesis of silicic magmas in the intraoceanic Kermadec arc. J. Petrol. 54, 351-391 (2013).

60. de Ronde, C. E. J. et al. The anatomy of a buried submarine hydrothermal system, Clark volcano, Kermadec arc, New Zealand. Economic Geol. (in the press).

61. Worthington, T. J., Hekinian, R., Stoffers, P., Kuhn, T. \& Hauff, F. Osbourn Trough: Structure, geochemistry and implications of a mid-Cretaceous paleaspreading ridge in the South Pacific. Earth Planet. Sci. Lett. 245, 685-701 (2006).

62. Castillo, P. R., Londsdale, P. F., Moran, C. L. \& Hawkins, J. W. Geochemistry of mid-Cretaceous Pacific crust being subducted along the Tonga-Kermadec Trench: Implications for the generation of arc lavas. Lithos 112, 87-102 (2009).

63. Turner, S. et al. Magma evolution in the primitive, intraoceanic Tonga Arc: rapid petrogenesis of dacites at Fonualei volcano. J. Petrol. 53, 1231-1253 (2012).

64. Sandwell, D. T. \& Smith, W. H. F. Marine gravity anomaly from Geosat and ERS 1 satellite altimetry. J. Geophys. Res. B 102, 10,039-10,054 (1997).

65. CANZ. New Zealand Region Bathymetry. New Zealand Oceanographic Institute Miscellaneous Chart Series 73 (National Institute of Water and Atmosphere Research, Wellington, New Zealand, 1997).
66. Cande, S. C. \& Stock, J. Pacific-Antarctic-Australian motion and the formation of the Maquire Plate. Geophys. J. Int. 157, 399-414 (2004).

\section{Acknowledgements}

The captains and crews of R/V Tangaroa and R/V Sonne are thanked for their support and skill during the 2004 NZAPLUME III and 2005 TAN0205 and during the 2002/2003 SO168 Zealandia expedition. We furthermore wish to thank Roland Maas for laboratory assistance at Melbourne University and Silke Hauff for laboratory assistance at GEOMAR. Discussions with J. Gill, R. Sutherland, S. Henrys and M. Reyners helped to develop ideas in this paper. We also thank the German Federal Ministry for Education and Research (BMBF) for funding Sonne cruise 168. This project was supported by public research funding from the Government of New Zealand.

\section{Author contributions}

C.T. developed the idea and wrote the manuscript. B.D. introduced gravity concepts and with F.C.-T. performed and checked the gravity model. J.W., K.H., K.A.H. and F.H. performed the analyses of the isotope data and contributed them to the manuscript. H.C.S. performed the plate reconstructions. I.J.G., C.E.J.de.R., D.B., N.M., R.J.W. and J.A.G. contributed to the writing of the manuscript. K.A.H. also helped to develop the idea and contributed to the writing of the manuscript.

\section{Additional information}

Supplementary Information accompanies this paper at http://www.nature.com/ naturecommunications

Competing financial interests: The authors declare no competing financial interests.

Reprints and permission information is available online at http://npg.nature.com/ reprintsandpermissions/

How to cite this article: Timm, C. et al. Subduction of the oceanic Hikurangi Plateau and its impact on the Kermadec arc. Nat. Commun. 5:4923 doi: 10.1038/ncomms5923 (2014). 